УДК: 791.43 .03

ББК: $85.373(3)$

DOI: 10.30628/1994-9529-2021-17.1-51-71

received 13.12.2020, accepted 31.03.2021

ОЛЬГА ВАСИЛЬЕВНА КОЛОТВИНА

Российский государственный

гуманитарный университет,

Москва, Россия

ResearcherID: AAJ-3200-2021

ORCID: 0000-0003-2873-3604

e-mail:kolotvina@mail.ru

ИММЕРСИВНЫЕ ТЕХНОЛОГИИ

МЕДИАИСКУССТВА Х. ВАЛЬ ДЕЛЬ ОМАРА

( АПАНОРАМНОЕ ПЕРЕПОЛНЕНИЕ

ОБРАЗА", "ДИАФОНИЯ",

«ТАКТИЛЬНОЕ ВИДЕНИЕ»)

КАК ВЫРАЖЕНИЕ ЕГО КОНЦЕПЦИИ

«ТЕХНОМИСТИЦИЗМА»

Аннотация. В статье проанализированы три медиатехнологии по созданию иммерсивного полисенсорного инвайронмента, разработанные испанским режиссёром, инженером Хосе Валь дель Омаром ещё в период 1940-х-1960-х гг.: «апанорамное переполнение образа» (вариант мультипроекторного полиэкрана), «диафония» (система перекрестного звука), «тактильное видение» (пульсирующее освещение с эффектом дистанционного касания). Технологии рассмотрены в контексте ключевой творческой концепции режиссёра, названной им «техномистицизмом» и направленной на создание кинематографической аналогии мистического опыта посредством трансформации мистицизма испанской культуры (выраженного в средневековой поэзии, в документации экстазов, в светотеневых художественных стратегиях искусства барокко и пр.) в практику кинематографа.

Автор текста раскрывает, как перевод суггестивного художественного потенциала испанской мистики в иммерсивность кинотехнологий позволил 
Х. Валь дель Омару создавать арт-пространства, выводящие систему иллюзий за пределы визуального в особые режимы психологических переживаний. На примере фильмов режиссёра («Гранада в зеркале воды», 1955, и "Огонь в Кастилии», 1961) дан анализ оригинальности инженерного решения технологий, определены стратегии иммерсивности и их укоренённость в испанском мистицизме; квалифицировано эстетическое воздействие медиатехнологий на зрителей.

В статье показано, что иммерсивность достигается с помощью шоковой стратегии чередования эффектов суггестивности и остранения, а также за счёт расширения диапазона сенсорного восприятия зрителей и эффекта синестезии. Усилению эффекта суггестивного впечатления способствуют визуальные поэтические метафоры, открывающие зрителям исторически сложившуюся чувственную образность испанской мистики. Семантическое поле фильма с помощью оптико-световых технологий не просто визуализируется, но и иллюзорно материализуется в качестве объёмного изображения, что способствует стиранию границы между зрителями и зрелищем.

В целом стратегии воспроизводят свойственную испанскому католическому культурному опыту чувственную иммерсивность. Такие стратегии позволяли блокировать у зрителей механизмы психологического дистанцирования, вызывали эмоциональную вовлеченность в происходящее, а также аффективные состояния, способствующие погружению в арт-пространство. Подобные технологические инновации по созданию иммерсивных зрелищных аудиовизуальных сред выводили кинематограф Х. Валь дель Омара в сферу мультимедиа, и режиссёр по праву может считаться предтечей медиаарта, создателем арт-пространств, которые впоследствии получили название звуковых и видеоинсталляций.

Ключевые слова: Хосе Валь дель Омар, экспериментальное кино, техномистицизм, иммерсивные стратегии, кинематограф Испании, тактильное видение, кинотехнологии, медиатехнологии 
OLGA V. KOLOTVINA

Russian State University for the Humanities, Moscow, Russia

ResearcherID: AAJ-3200-2021

ORCID: 0000-0003-2873-3604

e-mail: kolotvina@mail.ru

\title{
IMMERSIVE TECHNOLOGIES
}

OF J. VAL DEL OMAR'S MEDIA ART

("APANORAMIC IMAGE OVERFLOW",

"DIAPHONY", "TACTILE VISION")

\section{AS AN EXPRESSION OF HIS CONCEPT \\ OF "MECHANICAL MYSTICISM"}

\begin{abstract}
The article analyzes three media technologies for creating an immersive polysensory environment, developed back in 1940-1960s by the Spanish film director and engineer Jose Val del Omar. The technologies are considered in the context of the director's key concept, which he called "mechanical mysticism". It was aimed at creating a cinematic analogy of mystical experience by transforming the mysticism of Spanish culture into cinematic technologies.

The author reveals how the conversion of the suggestive artistic potential of Spanish mysticism into the immersiveness of film technologies allowed J. Val del Omar to create art spaces that took the system of illusions beyond the visual into special modes of psychological experiences. On the example of his films (WaterMirror of Granada, 1955, and Fire in Castile, 1961), the author analyzes the originality of the engineering solutions of J. Val del Omar's technologies, defines the strategies of immersiveness and their rootedness in Spanish mysticism, qualifies the aesthetic impact of these media technologies on viewers.

The article demonstrates that immersiveness is achieved by using a shock strategy of interlacing the effects of suggestiveness and defamiliarization ("ostranenie"), as well as through the expansion of the range of the viewer's sensory perception and the effect of synesthesia. The suggestive impression effect is enhanced by visual poetic metaphors that reveal to the viewers the historically formed sensual imagery of Spanish mysticism. With the help of optical and light technologies, the semantic field of a film is not only visualized, but also illusively materialized as a three-dimensional image.
\end{abstract}


In general, the strategies reproduce the sensual immersiveness, which is inherent in the Spanish Catholic cultural experience. Such strategies block the viewers' psychological distancing mechanisms and cause affective states and emotional involvement in the art spaces. Such technological innovations for creation of immersive spectacular audio-visual environments brought the J. Val del Omar's cinema into the field of multi-media, and therefore he could rightfully be considered the forerunner of media art, the creator of art spaces, which later became known as sound and video installations.

Keywords: Jose Val del Omar, experimental cinema, mechanical mysticism, immersive strategies, Spanish cinema, tactile vision, cinema technologies, media technologies

В арсенале современного медиаискусства стратегии иммерсивности являются главным ресурсом формального и содержательного обновления. Но эффекты погружения в арт-пространство, стирающие границу между зрителем и зрелищем, не являются инновацией цифровой эпохи, они имеют прецеденты в свойственных доцифровому искусству техниках иллюзорности. Так, медиатеоретик О. Грау показал в своём исследовании генезис иммерсивных визуальных пространств от иллюзионизма фресок Помпей и интерьеров барокко до виртуального искусства [1]. Подобный ретроспективный подход позволяет уточнить пути реализации эстетических возможностей доцифрового искусства на новом технологическом уровне. Точкой предельной проблематизации такой иллюзорности становится использование медиахудожниками иммерсивных возможностей художественных стратегий религиозного искусства, обладающих неисчерпаемым суггестивным потенциалом.

В современных исследованиях о религиозном медиаискусстве наблюдается тенденция к изучению работ ограниченного числа художников: рассматривается, как правило, видеоискусство Б. Виолы и Ш. Нешат (C. Vara Sánchez, R. Bernier, A. Gonzalo Carbó [2, 3, 4]). Но в истории медиаарта есть оригинальные и отчасти маргинальные фигуры, соединившие в своём творчестве современные технологии и религиозные практики. В связи с этим представляется актуальным проанализировать иммерсивные медиа разработки испанского режиссёра X. Валь дель Омара (José Val del Omar, 1904-1982), основанные на переосмыслении национального художественного наследия Испании и трансформации суггестивного потенциала испанского мистицизма в иммерсивность кинотехнологий. В целом для испанского авторского кинематографа (Л. Буньюэль, К. Сакура, 
П. Альмодовар и др.) характерна глубокая взаимосвязь с мистицизмом эстетических стратегий барокко. Х. Валь дель Омар работал в русле этой традиции, но он был не только режиссёром, но и инженером-изобретателем, создававшим с помощью доцифровых оптико-звуко-световых технических средств полисенсорные зрелищные арт-пространства, расширяющие систему иллюзий за пределы визуального, что позволяет считать его одним из пионеров медиаискусства в Испании.

Имя Х. Валь дель Омара практически не известно российскому зрителю, за исключением киноведов и культурологов (краткое упоминание о режиссёре есть в каталоге выставки «Лицом к будущему. Искусство Европы 1945-1968» [5, с. 56-57], анализу одного из его фильмов посвящена статья автора данного текста [6, с. 296-305]). В Испании в последнее время наблюдается рост интереса к его творчеству. Работы Х. Валь дель Омара вошли в постоянную экспозицию Национального музея Центра искусств королевы Софии в Мадриде. Современные испанские медиахудожники Ниньо де Эльче (Niño de Elche), Хавьер Вивер (Javier Viver), принимающие активное участие в реконструкции художественного и технического наследия X. Валь дель Омара, развивают его идеи и стремятся к созданию иммерсивных пространств в своих арт-проектах.

Отдельные аспекты проблематики взаимосвязи религиозных практик и иммерсивных стратегий в предложенных X. Валь дель Омаром инженерных решениях анализировались в работах Р. Губерна [7], М. Лосады [8], С. Риверо-Наварро [9], но фрагментарно и без конкретизации.

Научная новизна нашего исследования заключается в определении специфики работы с суггестивным потенциалом художественной традиции мистицизма в кинотехнологиях и в выявлении основных стратегий достижения иммерсивности в кинематографических практиках X. Валь дель Омара. Результаты работы могут быть востребованы медиахудожниками и специалистами по кинотехнологиям в качестве примеров идей, подлежащих воплощению в творчестве.

Мы рассмотрим три основные иммерсивные медиатехнологии Х. Валь дель Омара, разработанные им в 1940-е-1960-е гг. («апанорамное переполнение образа», «диафония», «тактильное видение») через творческую концепцию режиссёра - идею «техномистицизма». Свои технические инновации режиссёр понимал как неотъемлемую часть художественного языка фильмов “Гранада в зеркале воды» (“Aguaespejo Granadino", 1955) и “Огонь в Кастилии» (“Fuego en Castilla”, 1961), которые 
входят в мистическую кинотрилогию «Триптих Первостихий Испании» (“Tríptico Elemental de España”, 1955-1982/1995¹). Поэтому рассмотрение технологий будет проведено на материале отмеченных фильмов.

Период формирования Х. Валь дель Омара как режиссёра пришелся на 1930-е гг., проведенные в качестве волонтёра-кинооператора и фотографа в Педагогических Миссиях (исп. Las Misiones Pedagógicas). На протяжении нескольких лет вместе с будущим философом-эссеистом М. Самбрано, поэтами Л. Сернудой, Ф. Гарсиа Лоркой и другими представителями творческой интеллигенции он участвовал в государственном проекте медиаобразования неграмотного населения горных районов Испании. Путешествие по Испании с Миссиями позволило Х. Валь дель Омару ознакомиться с этнографическими особенностями разных регионов страны, совершенствовать навыки кинооператора (он снял более 40 фильмов ${ }^{2}$, сделал сотни фотографий), а также проникнуться идеалами его соратников по Миссиям; в частности, М. Самбрано открыла Х. Валь дель Омару поэзию св. Иоанна Креста. Во время кинопоказов Х. Валь дель Омар смог изучить на практике психологию восприятия движущегося образа людьми, никогда прежде не видевшими кино. Он обратил внимание на интенсивную аффективную реакцию неискушенных зрителей-крестьян, напомнившую ему религиозный экстаз. И эту реакцию он осознал как идеал кинематографического опыта, к созданию которого должен стремиться режиссёр.

Вышеперечисленные обстоятельства помогли ему сформировать свою концепцию кинематографа «техномистицизма» (исп. mecamística) ${ }^{3}$, способного ввести человека в состояние эмоционального потрясения и духовных переживаний. Техномистицизм - философская идея, лежащая в основе моих технических изобретений для передачи эмоциональности нашей культуры» [10, р. 279], - пояснял Х. Валь дель Омар, - «Я верю в возможность испанского кино, <созданного> в соответствии с нашей вертикалью, ... с нашим меридианом ... на грани реализма и мистики» [11]. В соответствии с этой целью режиссёр в своём творчестве использовал образы, идеи, стратегии художественного наследия мистицизма испанской культуры (выраженного в средневековой поэзии, в живописи художников

\footnotetext{
${ }^{1}$ Третий фильм трилогии “Acariño Galaico (De barro)" был завершен в 1995 г., после смерти Х. Валь дель Омара (в 1982 г.), режиссером Дж. Кодесалом (J. Codesal).

2 Большинство фильмов не сохранилось.

${ }^{3}$ Mecamística (исп.) - неологизм, объединяющий два слова: "mecánica" и "mística”.
} 
Золотого века Испании, в светотеневых художественных стратегиях искусства барокко и пр.) и трансформировал их в практики кинематографа.

«Х. Валь дель Омар стремился посредством кинематографа, подчёркивают исследователи Т. Соролла Ромеро и А. Лоригилло-Лопес, - заставить зрителя осознать себя, пережить зрелище, выходящее за привычные рамки кинематографической фантастики, привести зрителя к мистическому опыту, основанному на объединении части испанской художественной традиции и ... аудиовизуальной техники, изобретенной режиссёром» $[12$, р. 13].

Для понимания того, насколько удался этот кинематографический проект, нам необходимо, во-первых, описать инженерное решение технологий Х. Валь дель Омара, в том числе и на примере его кинокартин, в которых они использовались; во-вторых, выделить стратегии иммерсивности, применённые режиссёром, и, по возможности, проанализировать их генезис из наследия испанского мистицизма или из других источников; в-третьих, оценить эстетическое воздействие технологий на зрителей и определить результативность достижения поставленных режиссёром в рамках идеи «техномистицизма» задач по созданию особого арт-пространства.

Первое значительное изобретение Х. Валь дель Омара в области иммерсивных технологий связано с акустикой. В 1944 г. он патентует аудиосистему перекрестных помех, названную им "диафоническим звуком» или “диафонией» (исп. "sonido diafónico", “diafonía”). Она была впервые продемонстрирована в 1956 г. в Берлине на показе фильма «Гранада в зеркале воды» (1955). Для саундтрека 20-минутного фильма Х. Валь дель Омаром были записаны две разные аудиодорожки, содержащие более 500 звуковых элементов (цитаты испанских поэтов, мелодии гитары, органа, шум воды, шёпот, отрывки из колыбельных песен, фламенко и пр.).

Система "диафонии» состояла (как минимум) из двух динамиков. Один динамик, расположенный перед экраном, озвучивал действие на экране; второй, размещенный за зрителями, транслировал субъективные звуки (шорохи, неразличимый шёпот, вздохи, шум города), не соответствующие и иногда даже мешающие основному аудиоряду, сопровождавшему повествование, второй аудиоканал включался в определенные моменты действия. Два разных аудиотрека, звучавшие из стоящих на противоположенных концах зала динамиков, вступали в конфронтацию, зрители не могли объяснить наличие субъективных звуков и найти реальную причину для этого на экране, поэтому чувствовали дискомфорт. 
Мы видим, что режиссёр отказался от общепринятого в то время использования в кинематографе одного или нескольких аудиоканалов, транслирующих единственный информационный звуковой поток (стереофоническая система). «Диафония» Х. Валь дель Омара базировалась на передаче не согласующихся друг с другом звуковых потоков, и зрители оказывались на пересечении разнородных акустических полей.

Такая организация звука позволяла получить иммерсивное артпространство. Во-первых, по замыслу Х. Валь дель Омара, второй аудиоканал с субъективным звуком должен был активизировать ассоциативное мышление зрителей, пробудить в них память о пережитых ими событиях с целью включить эти воспоминания в процесс переживания и осмысления происходящего на экране. Во-вторых, шорохи, шумы, шёпот, исходящие из динамика за спиной зрителей, создавали иллюзию реальной открытой среды (в замкнутом пространстве кинозала) и вынуждали их, с одной стороны, испытать эффект погружения в реальную среду, а с другой насторожиться, выйти из состояния пассивного восприятия, потому что взаимодействие зрителей с происходящим на экране дополнялось вмешательством третьего «участника» - субъективного звука, источник которого зрители определить не могли.

Подобное взаимодействие субъективного звука с основным создавало чередование эффекта остранения (в тот момент, когда включался второй аудиоканал и звуки вступали в диссонанс, отвлекая зрителей от происходящего на экране) и эффекта погружения (если субъективный звук не включался или его содержание помогало создать иллюзию реальной среды). Такая дихотомия остранения и погружения являлась шоковой по воздействию на зрителей и представляла собой новый аспект в аудиостратегии иммерсивности.

Близкую позицию в оценке роли шоковых стратегий в кинематографе Х. Валь дель Омара занимает исследователь С. Риверо-Наварро: «Подобно тому, как Буньюэль и Дали хотят приостановить рациональный контроль с помощью визуального шока, Х. Валь дель Омар предлагает использовать кинематографические технологии, чтобы вызвать у зрителя шок, который динамизирует мистический взрыв» [9, р. 278]. И действительно, сочетание эффектов суггестивности и остранения, вызывающее шок у зрителей, характерно для испанского авторского кинематографа. В фильмах Л. Буньюэля, К. Сауры, П. Портабельи мы находим этот приём, ведущий к увеличению эмоциональной вовлеченности зрителей в происходящее на экране. Так, например, фильмы К. Сауры отличаются совмещением разных пластов реальности в киноповествовании: смешение 
сюжета пьесы и реальной жизни («Кармен», 1983), воображения и реальности («Выкорми ворона», 1975) приводит к усилению иммерсивного воздействия его фильмов на зрителей.

К применяемым X. Валь дель Омаром техникам, вызывающим шок, можно отнести не только звуковые эффекты, но и изобретённые режиссёром технологии мультиэкранной проекции изображений и художественной светопульсации, которые будут проанализированы далее.

Технология «апанорамного переполнения образа" (исп. "desbordamiento apanorámico de la imagen") была запатентована Х. Валь дель Омаром в 1955 г. и продемонстрирована (вместе с системой «диафонии») в 1956 г. на премьере фильма «Гранада в зеркале воды» (1955) - лирического аудиовизуального эссе, в котором образы садово-паркового ансамбля Альгамбры чередуются с их отражениями в воде.

Технология представляла собой уникальный вариант организации полиэкрана, позволявший объединить два потока изображений. Один поток образов, демонстрируемый на центральном экране, являлся нарративом фильма; второй, состоявший из связанных с основным повествованием нефигуративных образов, располагался вокруг основного экрана, свободно размещаясь на поверхностях стен, пола, потолка кинозала. То есть образ «переполнялся», перетекал за рамки экрана на зрителей (Рис. 1).

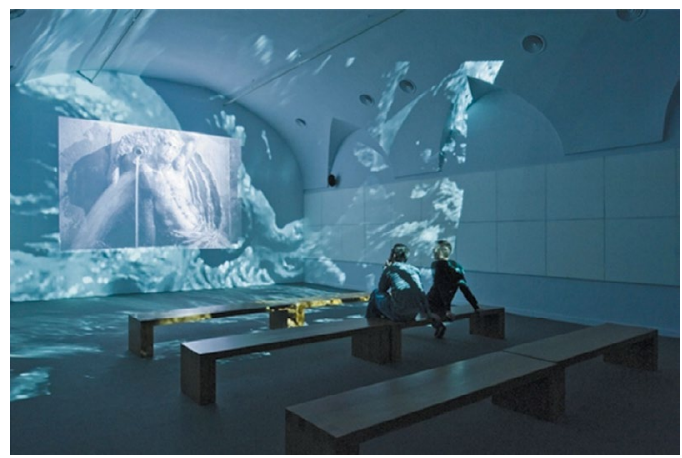

Рис. 1. Кинопроекция с помощью технологии «апанорамного переполнения образа»

Fig. 1. Film projection using "apanoramic image overflow" technology ${ }^{4}$

Для осуществления этой двойной концентрической проекции изображений Х. Валь дель Омар использовал набор специальных линз, при-

\footnotetext{
4 Источник изображения см. / See the image source: URL: http://elii.es/en/portfolio/ desbordamiento-val-de-omar-2/\#prettyphoto[gal]/2/ (дата обращения: 09.02.2021).
} 
крепленных к проектору. Предлагался и более простой вариант: размещение вокруг основного экрана зеркал разной степени вогнутости, в таком случае зеркала отражали бы в окружающем пространстве детали происходящего на главном экране.

Поиски способов выхода экрана за стандартные прямоугольные рамки, в том числе и с целью заинтересовать зрителей эффектами иммерсивности, характерны для технологических экспериментов этой эпохи: синерама - панорамная кинематографическая система, запатентованная Ф. Уоллером в 1952 г.; синемаскоп - упрощенный вариант синерамы, использующий одну плёнку вместо трех и один специальный объектив (запатентован в 1953 г. кинокомпанией «XX век Фокс»); в 1950-е-1960-е гг. появляется циркорама или круговая кинопанорама, основанная на разделении экрана сферической формы на части, на каждую из которых отдельным кинопроектором проецируется отдельное изображение, являющееся фрагментом целого.

Уникальность варианта двойного полиэкрана Х. Валь дель Омара заключалась прежде всего в аналогии между двойной кинематографической проекцией и функционированием человеческого зрения: область главного экрана (чёткий фокус зрения) была окружена другой областью, не нуждающейся в чёткой фокусировке (периферическое зрение). Нефигуративные изображения, растекаясь из второй проекции, воздействовали на периферическое зрение зрителя, пробуждая ассоциации и воспоминания, и служили, по мнению Х. Валь дель Омара, своего рода мостом между зрелищем на экране и зрителем.

Иммерсивная кинематографическая среда создавалась не только за счёт кинопроекции, но также благодаря основному визуальному мотиву фильма - образу воды (в виде ручьев, прудов, струй фонтанов), который идеально подходил для демонстрации «апанорамного переполнения». Технология была аналогична по своим свойствам водной стихии - проецируемые изображения растекались как вода и заполняли зрительный зал.

В этом фильме образ Гранады осмыслен режиссёром как точка схождения Востока и Запада. Исламо-католическая дихотомия двух культур раскрыта в кинокартине и с помощью суггестивной символики водной первостихии. В христианстве вода является символом освящения, крещения, Божественной благодати. В исламе вода наделяется священными свойствами как источник жизни и символизирует милосердие Аллаха. Образы воды, «изливавшиеся» с помощью проекционной технологии на 
зрителей, в сочетании с сюжетом несли в себе метафорику благодати, милосердия, вездесущности Бога, создавая семантическое поле, включавшее значения очищения, обновления, преображения, соединения с Первоосновой, что способствовало усилению суггестивного эффекта погружения зрителей в арт-пространство.

Как считает испанский киновед М. Лосада, Х. Валь дель Омар визуализировал в этом фильме поэтические образы св. Иоанна Креста (XVI в.), передававшего через метафору воды вездесущность Бога, Его силу и благодать: экранизация поэтических метафор дополнялась в фильме "творческим использованием произведения испанского поэта-мистика св. Иоанна Креста для создания кинематографической аналогии элементам мистической мысли» [8, р. 101].

Таким образом, мы видим, что Х. Валь дель Омар обращался к аутентичной мистической традиции в поисках стратегий для создания иммерсивного арт-пространства. Выход изображений водной первостихии за рамки двумерной экранной проекции вынуждал аудиторию взаимодействовать с чувственно-иммерсивными потоками образов, что позволяло зрителям пережить иллюзорный эффект погружения в мир видений средневековых мистиков.

Технология "тактильного видения" (исп. "visión tactil"), запатентованная Х. Валь дель Омаром в 1955 г., основана на использовании при киносъёмке световых потоков, преломляющихся через специальные линзы, зеркала, фильтры и направленных на определенные области снимаемого объекта в виде импульсов с разными временными интервалами. Яркость и продолжительность светопульсации зависела от драматургического замысла режиссёра. Такая стратегия подчёркивала рельеф и объёмность фактуры благодаря светотеневым эффектам, позволявшим добиться ощущения трёхмерного изображения и создать иллюзию дистанционного касания.

Разработкой технологии «тактильного видения» Х. Валь дель Омар занимался на протяжении десятилетий. Ещё в 1928 г. в интервью мадридскому еженедельнику "Экран» он заявил о своём намерении сделать «рельефный кинематограф» [13, р. 21]. Для этого он планировал использовать не только оптику, что было характерно для систем стереокинематографа (вызывавшего у зрителей иллюзию глубины пространства за счёт оптических эффектов), но и особым образом организованную систему световых потоков, формировавших объёмное изображение. 
Художественный потенциал технологии «тактильного видения» Х. Валь дель Омар раскрыл в фильме «Огонь в Кастилии» (1961), показав, как основной визуальный образ кинокартины (огонь) трансформируется в дистанционно осязаемое зрителями пламя. Фильм принес режиссёру международное признание. В 1961 г. на XIV кинофестивале в Каннах работа «Огонь в Кастилии» завоевала главный приз среди короткометражных фильмов в номинации за технические эффекты.

Материалом для кинокартины послужили сцены уличных религиозных процессий Страстной Пятницы в г. Вальядолид и полихромные статуи работы Алонсо Берругете и Хуана де Хуни (XVI в.) из Музея национальной скульптуры (Вальядолид). Особенно часто в фильме использовалась скульптура св. Анны работы Хуана де Хуни (Рис. 2, 3).

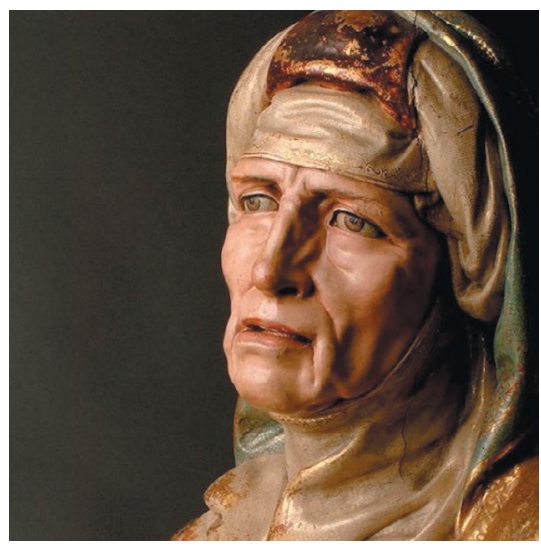

Рис. 2. Скульптура св. Анны.

Хуан де Хуни (XVI в.).

Национальный музей скульптуры

в г. Вальядолиде

Fig. 2. Sculpture of St. Anna.

Juan de Juni (16th century).

National Museum of Sculpture

in Valladolid ${ }^{5}$

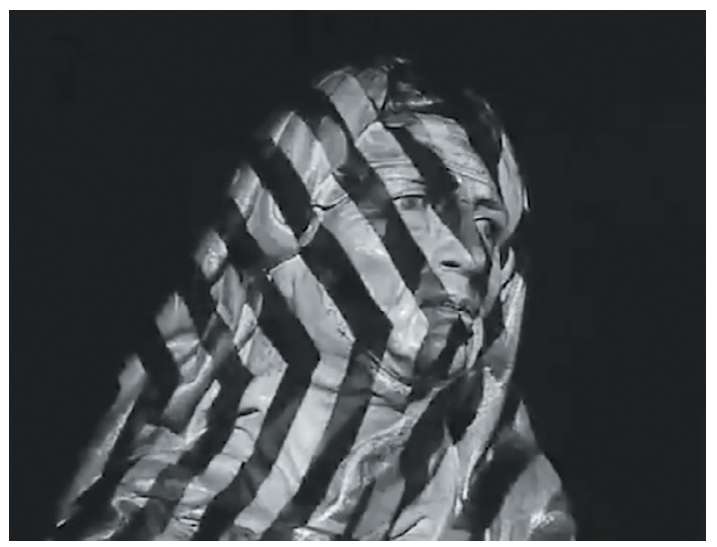

Рис. 3. Кадр из фильма «Огонь в Кастилии»

Fig. 3. Screen capture from the film Fire in Castile ${ }^{6}$

\footnotetext{
${ }^{5}$ Источник изображения см.: / See the image source: URL: http://www.culturaydeporte.gob.es/ mnescultura/colecciones/escultura-espanola.html (дата обращения: 09.02.2021).

6 Источник изображения см.: / See the image source: URL: https://www.youtube.com/ watch?v=EwOd2TFuAlw (дата обращения: 10.02.2021).
} 
Дополнительной техникой освещения Х. Валь дель Омар усилил присущую барочной скульптуре эмоциональность и фактически анимировал статуи таким образом, что они казались ожившими. Лица скульптур под воздействием световых импульсов, подчёркивающих рельеф морщин, приобретали живую мимику, а искажение изображений с помощью разных фильтров в виде геометрических рисунков или растительных орнаментов привносило новое понимание нюансов душевного состояния персонажей (Рис. 4, 5).

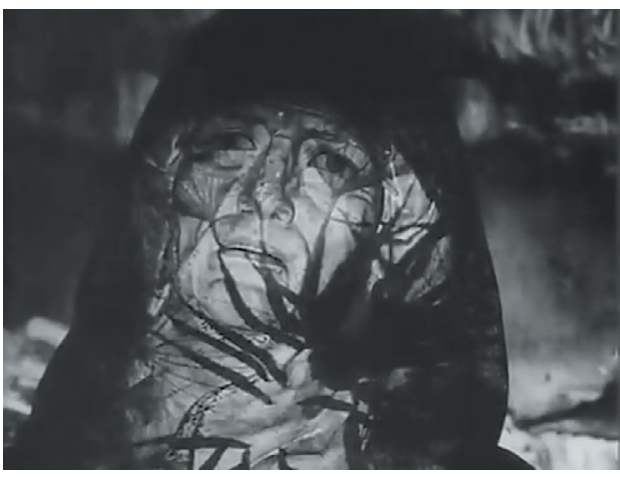

Рис. 4. Кадр из фильма "Огонь в Кастилии»

Fig. 4. Screen capture from the film Fire in Castile

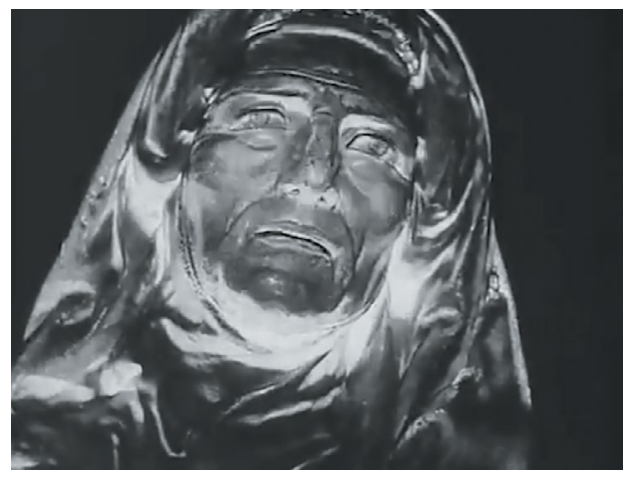

Рис. 5. Кадр из фильма «Огонь в Кастилии»

Fig. 5. Screen capture from the film Fire in Castile ${ }^{8}$

В фильме инсценируются эпизоды Священного писания с использованием скульптур пророков, святых, мучеников, Богоматери, Спасителя. Душевные и физические мучения персонажей передаются световыми вибрациями, деформирующими их тела (Рис. 6, 7). Свет, атакующий скульптуры, «расплавляет» их лица (Рис. 5, 6, 7) и зритель почти физически ощущает страдания, «претерпеваемые» святыми под воздействием пламени. Например, световые модификации лица скульптуры св. Анны работы Хуана де Хуни передают целую гамму душераздирающих чувств (Рис. $3,4,5)$.

\footnotetext{
7 Источник изображения см.: / See the image source: URL: https://www.youtube.com/ watch?v=EwOd2TFuAlw (дата обращения: 10.02.2021).

8 Источник изображения см.: / See the image source: URL: https://www.youtube.com/ watch?v=EwOd2TFuAlw (дата обращения: 10.02.2021).
} 


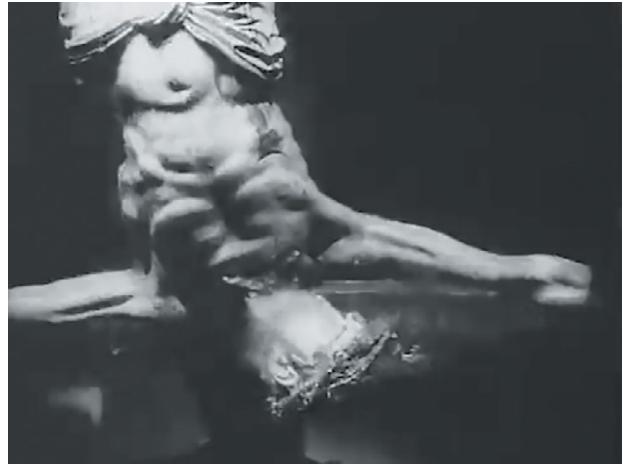

Рис. 6. Кадр из фильма «Огонь в Кастилии»

Fig. 6. Screen capture from the film Fire in Castile ${ }^{9}$

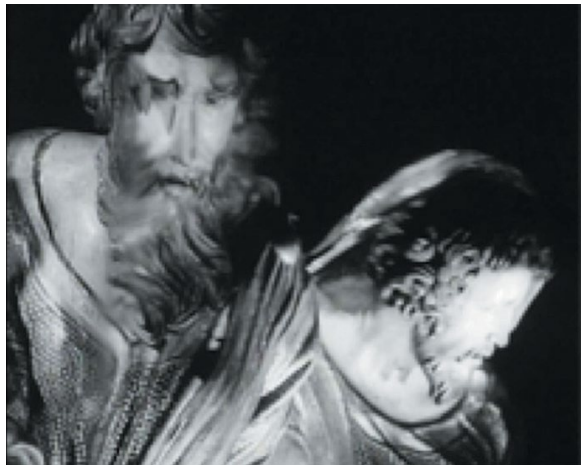

Рис. 7. Кадр из фильма «Огонь в Кастилии»

Fig. 7. Screen capture from the film Fire in Castile ${ }^{10}$

Мистерия Страстной Пятницы воспроизводится в фильме на соединении двух миров: художественного, где библейские персонажи, страдая от боли и ужаса, переживают вселенскую катастрофу (распятие Христа), и реального. Таким образом зрители вовлекаются в художественное пространство фильма через мерцание световых вибраций, освещающих и дистанционно пальпирующих их лица и тела. Пульсация световых импульсов с развитием действия ускоряется, звуковое сопровождение в виде ритма сердцебиения становится более интенсивным, что приводит к эффекту погружения зрителей в «пульсирующее, личное, лирическое, мистическое зрелище, которое может дать им эмоциональную новизну экстаза» [14, р. 109].

Как и древнегреческий философ Эмпедокл, Х. Валь дель Омар считал, что зрение является продолжением тактильного чувства. Технология «тактильного видения» основывалась на понимании режиссёром зрения как совершенного осязания, использующего свет для восприятия реальности: «Когда кто-либо из нас смотрит на объект, чтобы узнать его форму... он пальпирует его двумя чувствительными поверхностями сетчатки», «необходимо преобразовать свет в осязаемую вибрацию» [15, р. 113, р. 116].

\footnotetext{
${ }^{9}$ Источник изображения см.: / See the image source: URL: https://www.youtube.com/ watch?v=EwOd2TFuAlw (дата обращения: 10.02.2021).

10 Источник изображения см.: / See the image source: URL: https://www.youtube.com/ watch?v=EwOd2TFuAlw (дата обращения: 10.02.2021).
} 
Для осуществления этого проекта режиссёр разработал систему свето-оптических механизмов и фильтров, с помощью которых можно было моделировать яркость и длительность световых импульсов, «силу» дистанционного тактильного прикосновения и, тем самым, пробуждать творческую фантазию зрителей. Это позволяло, как считают испанские киноведы Гонсало де Лукас и И. Пинтор Ирансо, «приблизиться к тотальному и трансформирующему кинематографическому опыту, основанному на тактильном участии ... Посредником в опыте трансцендентного было воображение человека» [16, р. 166].

Отметим, что светотеневые эксперименты в искусстве с целью придания объёмности изображаемому объекту и для визуализации сакральных характеристик бытия характерны для авангардных практик XX в., претендовавших на активную трансформацию пространства и создание оптики нового типа. Технологию Х. Валь дель Омара можно охарактеризовать и как версию светового кубизма, предтечей которого могла быть живопись П. Пикассо, «лучизм» М. Ларионова, кинематограф немецкого экспрессионизма и пр.

Мы видим, что светотеневые практики Х. Валь дель Омара, совпадая по некоторым формальным характеристикам с творчеством художников авангарда, базировались тем не менее на своеобразной философии тактильного зрения и имели религиозные цели. Так, чилийский исследователь Ф. Куссен акцентирует внимание на понимании Х. Валь дель Омаром своего творчества как религиозной миссии, в которую входило в том числе и создание «устройств для чрезмерного возбуждения чувств, ... своего рода инструментов для трансмутации внешних органов в органы души, о которых так много говорили мистики» [17].

Несмотря на то, что наследие авангардной световой трансформации пространства было инструментализировано в 1950-е-1970-е гг. в опарте, Х. Валь дель Омар обратился не к современным интерпретациям, окрашенным прагматикой авангарда, а к локальной испанской традиции барокко, где в световых стратегиях нашла воплощение насыщенная семантика религиозного чувства. Подробно изучить художественные особенности произведений живописцев Золотого века Испании Х. Валь дель Омар мог в 1930-е, принимая участие в качестве волонтёра в Педагогических Миссиях. В передвижном музее Миссий были репродукции картин Х. Риберы, Ф. Сурбарана, Д. Веласкеса, Б.Э. Мурильо и др. Близко познакомиться с оригиналами произведений испанских живописцев Х. Валь дель 
Омар имел возможность в конце 1940-х, участвуя в подготовке к эвакуации картин Музея Прадо.

Техники мистического тенебризма испанских живописцев Х. Риберы, Ф. Сурбарана, использовавших светотеневые эффекты для передачи эмоциональных состояний, глубины драматических переживаний героев, для подчёркивания рельефности и объёма за счёт световых акцентов, переносились Х. Валь дель Омаром в кинематографическое пространство. Можно увидеть в технологии «тактильного видения» и влияние живописных приёмов французского художника Ж. Латура, чьи картины насыщены сакральным символизмом света. Однако, учитывая динамичность, остроту повествования и шоковый характер применённых в фильме «Огонь в Кастилии» световых стратегий, напряжённый драматизм живописи испанского барокко больше отвечал намерениям режиссёра.

Чувственный мистицизм испанской католической традиции экстатических видений также нашёл отражение в световой технологии Х. Валь дель Омара. Световые импульсы в виде ярких сполохов пламени, таинственного мерцания, дробных вспышек и плавных волн побуждали зрителей идентифицироваться с подвергавшимися светопульсации персонажами фильма, переживать вместе с ними их агонию и трансформацию не только созерцательно, но и отчасти телесно. Реакция на прикосновение пламени и вспышки света - дорациональная, инстинктивная, телесная: сжаться, отстраниться, почувствовать боль, пережить испуг. Таким образом, зритель неизбежно оказывался вовлечен в происходящее на экране через активизацию физиологических реакций. Истоки подобной иммерсивной стратегии - погружение в зрелище через аффективный, телесный опыт, через физический контакт (пусть и иллюзорный) - можно найти в описаниях экстазов католических святых, например, св. Тереза Авильская (XVI в.) полагала, что Ангел пронзил копьём её сердце, и она физически ощущала боль от этих ударов.

Надо отметить, что в своих кинематографических экспериментах $X$. Валь дель Омар не ограничивался аудиовизуальными каналами передачи информации, он изобретал полисенсорные технологии, задействующие такие чувства, как обоняние, осязание, опыт тела. Например, он предлагал во время кинопоказа распылять в воздухе запах трав тех регионов, о которых повествует фильм, а на премьере фильма «Огонь в Кастилии» в Каннах (1961) зрителям раздали небольшие деревянные дощечки, на которые была нанесена липкая, пачкающая пальцы, сильно пахнущая смола. Тем самым, запах и ощущение вязкой смолы на коже рук способство- 
вали более чувственному восприятию рельефности фактуры кинообраза и раскрытию мистической интуиции, связанной с тактильным зрением.

Обобщая анализ медиатехнологий Х. Валь дель Омара, можно выделить несколько основных стратегий достижения иммерсивности.

Во-первых, применяемые режиссёром технологии расширяют диапазон сенсорного восприятия зрителей. Так, «апанорамное переполнение образа» оказывает воздействие на периферическое зрение и создает эффект присутствия в событиях, происходящих на главном экране. «Тактильное видение» световыми импульсами имитирует эффект дистанционного прикосновения, включая опыт тела в переживание зрителями событий кинофильма. Субъективный звук, конфликтующий с основным аудиорядом (в акустической технологии «диафонии»), вызывает диссонанс в восприятии и активизирует эмоциональную память зрителей.

Во-вторых, иммерсивность амплифицируется применением мультимедийных приёмов, создающих эффект синэстезии. Например, в технологиях Х. Валь дель Омара зрение объединяется с чувством осязания, воздействие на обоняние усиливает восприятие объёмности фактуры.

В-третьих, семантическое поле фильма с помощью оптико-световых технологий Х. Валь дель Омара не просто визуализируется, но и иллюзорно материализуется, так как эти технологии направлены на создание объёмного изображения, что позволяет зрителям не только видеть происходящее на экране, но и воспринимать его с помощью осязания. Отметим в этой связи и такую особенность художественных стратегий Х. Валь дель Омара, как воспроизведение в кинотехнологиях материальных характеристик визуальных образов его фильмов. Например, изображения, проецируемые с помощью «апанорамного переполнения образа», растекаются по зрительному залу как вода (основной визуальный мотив фильма «Гранада в зеркале воды»). Световибрации «тактильного видения» в фильме «Огонь в Кастилии» подобны огню и позволяют зрителям почувствовать «температуру» персонажа, его страдания и боль и в ряде случаев отождествиться с этой болью, пережить её как свою собственную.

В-четвёртых, усилению эффекта суггестивного впечатления способствует аудиовизуальное содержание фильмов: визуальные поэтические метафоры открывают зрителям чувственную образность испанской мистики; сложные, многосоставные саундтреки содержат ритмы фламенко и сольное пение канте хондо, создающее у зрителей трансово-иммерсивный настрой. 
B-пятых, в технологиях X. Валь дель Омара мы наблюдаем достижение иммерсивности с помощью шоковой стратегии чередования эффектов суггестивности и остранения. Трансово-медитативные состояния зрителей внезапно прерываются остранением, что, как это ни парадоксально, ведет к сокращению степени (или полной блокировке) психологической дистанцированности аудитории от зрелища. Такое антиномичное соединение остранения и суггестивности порождает эмоции, которые можно сопоставить со сверхчувственным опытом.

В целом стратегии, используемые Х. Валь дель Омаром, воспроизводят свойственную испанскому католическому культурному опыту чувственную иммерсивность, нашедшую своё выражение не только в семантических параметрах описаний экстазов и видений католических святых, но и в прагматике литературы, архитектуры, живописи, скульптуры, кинематографа Испании. Технологические разработки Х. Валь дель Омара, основанные на эстетизации культурной идентичности и раскрывающие суггестивный потенциал художественной традиции испанского мистицизма, весьма продуктивны на современном этапе развития визуальной культуры и технологий и могут быть интегрированы в мировое кинопроизводство.

\section{ЛИТЕРАТУРА}

1. Grau O. Virtual Art: From Illusion to Immersion. Cambridge, MA: The MIT Press, 2003. $430 \mathrm{p}$.

2. Vara Sánchez C. Bill Viola's Nantes Triptych: Unearthing the sources of its condensed temporality // Aniki. 2015. Vol. 2. № 1, pp. 35-48. DOI: 10.14591/aniki. v2n1.105.

3. Bernier R. The Unspeakable Art of Bill Viola: A Visual Theology. Eugene: Pickwick Publications, 2014. $100 \mathrm{p}$.

4. Carbó Gonzalo A. El viaje espiritual al «espacio verde»: el jardín de la visión en el sufismo // Convivium: revista de filosofía. 2007. № 20. P. 65-90.

5. Лицом к будущему. Искусство Европы 1945-1968: каталог к выставке. М.: ИПК Парето-Принт, 2017. 500 с.

6. Колотвина О.В. Экспериментальный кинематограф Х. Валь дель Омара: фильм “Огонь в Кастилии» как пример художественной интеграции // Художественные миры XXI века. Пути интеграции архитектуры и арт-практик: коллективная монография под ред. Т.Г. Малининой. М.: БуксМАрт, 2020. С. 296-305.

7. Gubern R. Val del Omar cinemista. Granada: Diputación de Granada, 2004. 120 p.

8. Losada M. San Juan de la Cruz in Tactilvisión: The technological mysticism of José Val del Omar's Tríptico elemental de España // Studies in Hispanic Cinemas. 2010. Vol. 7. № 2. P. 101-115. DOI: 10.1386/shci.7.2.101_1. 
9. Rivero-Navarro S. Epifanía, trance, arrebato y otras iluminaciones: manifestaciones extáticas en la cultura Ibero-Americana contemporánea. Doct. diss. Cambridge: Harvard University, 2014. 347 p. URL: http://nrs.harvard.edu/urn-3:HUL. InstRepos:17467239 (дата обращения: 15.12.2020).

10. Val del Omar J. Meca-Mística // Val del Omar J., Ortiz-Echagüe J. Escritos de técnica, poética y mística. Barcelona: Ediciones de La Central, 2010, pp. 279-280.

11. Val del Omar J. Manifiesto de la Asociación Creyentes del Cinema. URL: https:// www.valdelomar.com/pdf/text_es/text_29.pdf (дата обращения: 15.12.2020).

12. Sorolla Romero T., Loriguillo-López A. Tactilvisiones de lo intangible. Lo translúcido en Fuego en Castilla. 2016. URL: https://www.academia.edu/33641818/ Tactilvisiones_de_lo_intangible_Lo_translucido_en_Fuego_en_Castilla (дата обращения: 15.12.2020).

13. Gascón A. Un muchacho español logró dos inventos que revolucionarán el arte del cinema // Val del Omar. Más álla de la órbita terrestre / ed. by Dukue E. Buenos Aires: Ministerio de Cultura del Gobierno: BAFICI, 2015. P. 19-22.

14. Val del Omar J. La diafonía es un nueva sistema de producción // Val del Omar J., Ortiz-Echagüe J. Escritos de técnica, poética y mística. Barcelona: Ediciones de La Central, 2010. P. 108-110.

15. Val del Omar J. Teoría de la VisiónTactil // Val del Omar J., Ortiz-Echagüe J. Escritos de técnica, poética y mística. Barcelona: Edici ones de La Central, 2010. P. 113-117.

16. Lucas G. de, Pintor I. Poética del montajeen "Aguaespejo granadino": investigación estética, técnica y pedagógica sobre la experiencia del espectador en la obra de José Val del Omar // L’Atalante: revista de estudios cinematográficos. 2017. № 24. P. 165-184.

17. Cussen F. José Val del Omar: una pedagogía de la visión // Mula Blanca: revista de literatura y arte. 2015. 06 Feb. URL: http://mulablanca.com/jose-val-del-omar-unapedagogia-de-la-vision1 (дата обращения: 15.12.2020).

\section{REFERENCES}

1. Grau O. Virtual art: From illusion to immersion. Cambridge, MA: The MIT Press, 2003.

2. Vara Sánchez C. Bill Viola's Nantes Triptych: Unearthing the sources of its condensed temporality. 2014. 2 (1). DOI: 10.14591/aniki.v2n1.105.

3. Bernier R. The unspeakable art of bill viola: $A$ visual theology. Eugene, USA: Pickwick Publications, 2014.

4. Carbó Gonzalo A. El viaje espiritual al «espacio verde»: el jardín de la visión en el sufismo. Dialnet. 2007. URL: https://dialnet.unirioja.es/servlet/ articulo?codigo=2272391 (accessed 11.12.2020).

5. Litsom k budushchemu: Iskusstvo Evropy 1945-1968 [Facing the future: Art of Europe in 1945-1968]. Moscow: IPK Pareo-Print, 2017. 
6. Kolotvina O.V. Eksperimental'nyy kinematograf Kh. Val' del' Omara: Fil'm “Ogon' v Kastilii" kak primer khudozhestvennoy integratsii [Experimental cinematography of J. Val del Omar: "Fire in Castile" as an example of artistic integration]. In T.G. Malinina (Ed.), Hudozhestvennye miry XXI veka: Puti integrazii arhitekturyi art-praktik [Artistic worlds of the 21st century: Ways of integrating architecture and art practices] (pp. 296-305). BuksMArt, 2020.

7. Gubern R. Val del Omar cinemista. Granada: Diputación de Granada, 2004.

8. Losada M. San Juan de la Cruz in Tactilvisión: The technological mysticism of José Val del Omar's Tríptico elemental de España. Studies in Hispanic Cinemas. 2010. 7 (2), pp. 101-115. DOI: 10.1386/shci.7.2.101_1.

9. Rivero-NavarroS. Epifanía, trance, arrebato y otras iluminaciones: manifestaciones extáticas en la cultura Ibero-Americana contemporánea (Doctoral dissertation). 2015. DASH HarvardEDU. URL: http://nrs.harvard.edu/urn-3:HUL.InstRepos:17467239 (accessed 15.12.2020).

10. Val del Omar J. Meca-Mística. In Val del Omar J., Ortiz-Echagüe J., Escritos de técnica, poetica y mística (pp. 279-280). Barcelona: Central Ediciones, 2010.

11. Val del Omar J. Manifiesto de la Asociación Creyentes del Cinema. Valdelomar: website. URL: https://www.valdelomar.com/pdf/text_es/text_29.pdf (accessed 15.12.2020).

12. Sorolla Romero T., Loriguillo-López A. Tactilvisiones de lo intangible. Lo translúcido en Fuego en Castilla. 2016. URL: https://www.academia.edu/33641818/Tactilvisiones_ de_lo_intangible_Lo_translucido_en_Fuego_en_Castilla (accessed 15.12.2020).

13. Gascón A. Un muchacho español logra dos inventos que revolucionarán el arte del cinema. In E. Dukue (Ed.), Val del Omar: Más álla de la órbita terrestre (pp. 19-22). Buenos Aires: Ministerio de Cultura del Gobierno, BAFICI, 2015.

14. Val del Omar J. La diafonía es un nueva sistema de producción. In Val del Omar J., Ortiz-Echagüe J., Escritos de técnica, poética y mística (pp. 108-110). Barcelona: Central Ediciones, 2010.

15. Val del Omar J. Teoría de la Visión Tactil. In Val del Omar J., Ortiz-Echagüe J., Escritos de técnica, poética y mística (pp. 113-117). Barcelona: Central Ediciones, 2010.

16. Lucas G. de, Pintor I. Poética del montaje en "Aguaespejo granadino": investigación estética, técnica y pedagógica sobre la experiencia del espectador en la obra de José Val del Omar. L'Atalante: revista de estudios cinematográficos. 2017. (24), pp. 165-184.

17. Cussen F. José Val del Omar: una pedagogía de la visión. Mula Blanca: revista de literatura y arte, 2015. 6 February. URL: http://mulablanca.com/jose-val-del-omaruna-pedagogia-de-la-vision1 (accessed 15.12.2020). 


\section{СВЕДЕНИЯ ОБ АВТОРЕ}

\section{ОЛЬГА ВАСИЛЬЕВНА КОЛОТВИНА}

соискатель факультета истории искусства,

Российского государственного гуманитарного университета, 125993, г. Москва, Миусская площадь, 6

ResearcherID: AAJ-3200-2021

ORCID: 0000-0003-2873-3604

e-mail: kolotvina@mail.ru

ABOUT THE AUTHOR

\section{OLGA V. KOLOTVINA}

PhD student at the Faculty of Art History, the Russian State University for the Humanities, Miusskaya Square, 6, 125993, Moscow

ResearcherID: AAJ-3200-2021

ORCID: 0000-0003-2873-3604

e-mail: kolotvina@mail.ru 